\title{
Eksplorasi Faktor-Faktor Yang Mempengaruhi Kinerja Karyawan Grup Hubungan Kelembagaan Di Bank DKI
}

\author{
Aprilla Sinta Uli ${ }^{1}$, Amir Fikri ${ }^{2}$, Rini Yayuk Priyati ${ }^{3}$ \\ ${ }^{123}$ Pascasarjana Manajemen Sumber Daya Manusia, Universitas Terbuka \\ Email: 530032396@ecampus.ut.ac.id ${ }^{1 *}$
}

\begin{abstract}
Performance is a core problem in organizations since, no matter what the organization is, performance is a key statement to its effectiveness or success. It is believed that qualified Human Resources will support an effective organization. The Regional Bank is one of the government agencies that is currently being scrutinized for its performance. Bank DKI, as the Regional Development Bank, is entrusted in becoming a modern and high-value regional bank. The purpose of this research was to analyze the factors that affect the performance of employees in the institutional relations group at Bank DKI. The research was conducted at the Bank DKI Head Office, with all employees and leaders at the Group level at the Bank DKI Head Office serving as the research population. The convenience sampling method was utilized in this study's sampling technique, which was non-probability sampling. The sample consisted of all employees and leaders from Bank DKI's Institutional Relations Group. Convergent validation (loading factor and Average Variance Extracted/AVE) and discriminant validation were used in the validation test (former Lecker and cross loading). Cronbach's alpha and composite reliability (CR) with a limit value of 0.7 were used to conduct the reliability test. The study's findings indicate that work effectiveness and employee independence are the most important factors influencing employee performance at Bank DKI. Employee performance is influenced by factors such as motivation, work environment, job satisfaction, workload, and TQM.
\end{abstract}

Keywords: Influencing Factors, Employee Performance, Human Resources, Institutional Relations Group, Bank DKI.

Abstrak. Kinerja adalah isu aktual dalam organisasi karena apapun organisasinya, kinerja merupakan pernyataan kunci terhadap efektivitas atau keberhasilan organisasi. Organisasi yang efektif akan ditopang oleh Sumber Daya Manusia (SDM) yang berkualitas. Salah satu instansi pemerintah yang menjadi sorotan kinerja saat ini adalah Bank Daerah. Bank DKI sebagai Bank Pembangunan Daerah mempunyai tugas untuk menjadi bank regional modern dan bernilai tinggi. Penelitian ini bertujuan untuk mengeksplorasi factor-faktor yang mempengaruhi kinerja karyawan grup hubungan kelembagaan di bank DKI. Lokasi penelitian yaitu di Kantor Pusat Bank DKI dengan populasi penelitian adalah seluruh karyawan dan pemimpin setingkat Grup di Kantor Pusat Bank DKI. Teknik pengambilan sampel dalam penelitian ini adalah non probability sampling dengan metode convenience sampling. Sampel yang digunakan adalah seluruh karyawan dan pemimpin Grup Hubungan Kelembagaan di Bank DKI. Uji validasi terdiri dari validasi konvergen (loading factor dan Average Variance Extraced/AVE) dan validasi diskriminan (former Lecker dan cross loading). Uji realibilitas dilakukan dengan dua metode yaitu Cronbach's alpha dan composiate reliability (CR) dengan nilai batas 0.7 . Hasil penelitian menunjukkan Kinerja karyawan di Bank DKI didominasi oleh efektifitas kerja dan kemandirian karyawan. Sedangkan faktor-faktor yang mempengaruhi kinerja karyawan antara lain Motivasi, Lingkungan Kerja, Kepuasan kerja, Beban kerja,dan TQM.

Kata kunci: Faktor-faktor yang mempengaruhi, kinerja karyawan, Sumber Daya Manusia, Grup Hubungan Kelembagaan, Bank DKI. 


\section{PENDAHULUAN}

Kinerja adalah isu aktual dalam organisasi karena apapun organisasinya, kinerja merupakan pernyataan kunci terhadap efektivitas atau keberhasilan organisasi. Organisasi yang berhasil dan efektif merupakan organisasi dengan individu yang di dalamnya memiliki kinerja yang baik. Organisasi yang efektif akan ditopang oleh Sumber Daya Manusia (SDM) yang berkualitas. Banyak organisasi yang berhasil atau efektif karena ditopang oleh kinerja SDM yang baik (Akrani, 2018). SDM merupakan aset organisasi yang sangat vital, karena itu peran dan fungsinya tidak bisa digantikan oleh sumber daya lainnya. SDM menjadi tolak ukur dalam keberhasilan sebuah instansi/organisasi dalam mencapai kinerjanya (Kartika et al., 2018). Pada prinsipnya setiap instansi/organisasi memiliki barometer untuk menilai apakah roda organisasinya berjalan dengan baik atau terdapat hambatan dan tantangan dalam mencapai tujuan.

Salah satu instansi pemerintah yang menjadi sorotan kinerja saat ini adalah Bank Daerah. Sebagai salah satu instansi Badan Usaha Milik Daerah DKI Jakarta, Bank DKI berupaya tetap tumbuh di tengah pandemi dengan membukukan penyaluran kredit pada Laporan Kinerja Semester I tahun 2020 dengan pertumbuhan hingga 8,3 persen sebesar Rp 31,98 triliun per Juni 2020 sedangkan dana pihak ketiga hanya tumbuh sebesar 5,3 persen sebesar Rp 35,40 triliun pada Juni 2020, berbeda dari target Rencana Bisnis Bank (RBB) yang diharapkan oleh Bank DKI yaitu sebesar $10,2 \%$.

Bank DKI sebagai Bank Pembangunan Daerah mempunyai tugas untuk menjadi bank regional modern dan bernilai tinggi yang menjaga keseimbangan antara keuntungan dan pembangunan DKI Jakarta. Berdasarkan tier Bank Umum Kegiatan Usaha (BUKU), saat ini Bank DKI berada pada Bank BUKU III dengan total asset sebesar Rp 63,08 Triliun pada akhir tahun 2020. Berikut adalah data perbandingan total asset Bank Daerah yang berada pada Bank BUKU III:
Tabel 1. Total Asset Bank Daerah BUKU III Tahun 2020

\begin{tabular}{|c|c|c|}
\hline No & Nama Bank & $\begin{array}{c}\text { Total Asset } \\
\text { (triliun) }\end{array}$ \\
\hline 1 & Bank BJB & 140,90 \\
\hline 2 & Bank Jatim & 83,62 \\
\hline 3 & Bank Jateng & 73,11 \\
\hline 4 & Bank DKI & 63,08 \\
\hline
\end{tabular}

Berdasarkan Tabel 1 di atas, dapat dilihat bahwa Bank DKI berada pada posisi terbawah dengan nilai total asset sebesar 63,08 Triliun. Total asset yang dimiliki Bank DKI adalah 98,7\% dari penyerapan APBD DKI Jakarta Tahun 2020 yaitu sebesar 63,89 Triliun. Hal tersebut menunjukan bahwa gambaran kinerja yang dihasilkan oleh Bank DKI pada tahun 2020 belum maksimal, terutama dalam penghimpunan dana pihak ketiga sebagai angka pengukuran total asset. Penilaian kinerja karyawan Grup Hubungan Kelembagaan di Bank DKI dilakukan berdasarkan Key Perfomance Indicator (KPI). Berikut ini adalah grafik penilaian kinerja karyawan di Grup Hubungan Kelembagaan Bank DKI dengan menggunakan pencapaian total penghimpunan dana korporasi (dana pihak ketiga) setiap tahunnya berdasarkan nominal rupiah.

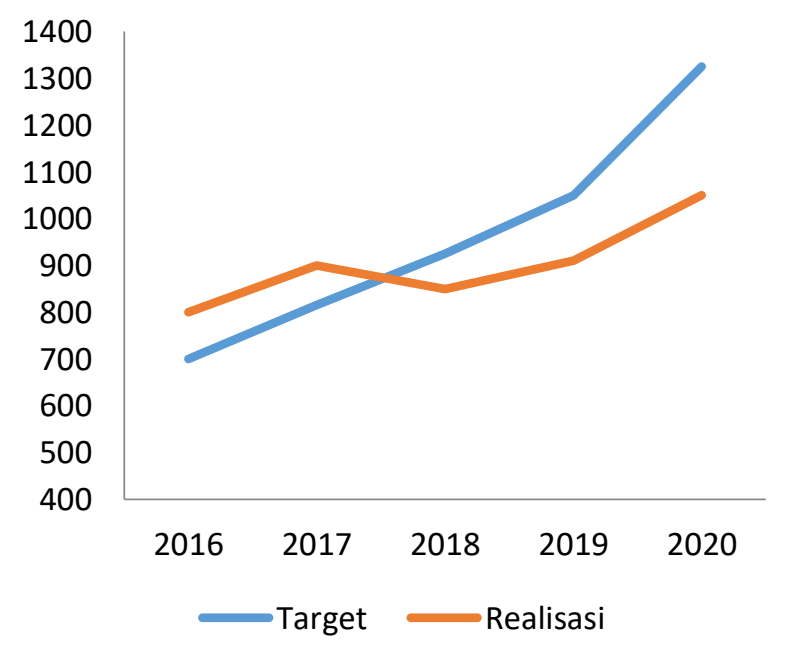

Gambar 1. Pencapaian Kinerja Grup Hubungan Kelembagaan (Milyar Rupiah)

Pada gambar diatas dapat disimpulkan bahwa target yang ditentukan kepada karyawan Grup Hubungan Kelembagaan Bank DKI selama lima tahun terakhir mengalami peningkatan dari tahun 2016 hingga tahun 2020. Dari lima tahun terakhir, pencapaian yang 
melampaui target hanya terjadi pada tahun 2016 dan 2017. Pada tahun 2018, pencapaian atas penghimpunan dana korporasi menurun signifikan dari target yang meningkat setiap tahunnya. Tren realisasi penghimpunan dana korporasi pada tahun selanjutnya masih belum memenuhi target yang telah ditentukan. Penurunan pencapaian ini dapat mempengaruhi penilaian kinerja karyawan (Al-Damen, 2017).

Sebagai instansi yang bergerak dibidang jasa dan pelayanan, kinerja Bank DKI berfokus pada kualitas mutu yang diberikan kepada nasabah (customer focused) dengan melibatkan semua level karyawan dalam melakukan peningkatan atau perbaikan yang berkesinambungan (secara terus-menerus) atau yang disebut dengan Total Quality Management (TQM). TQM diartikan sebagai konsep dalam menggunakan strategi, data dan komunikasi yang efektif untuk mengintegrasikan kedisplinan kualitas untuk mencapai keberhasilan jangka panjang (Sallis, 2017). Berikut ini adalah hasil rangkuman penilaian nasabah yang diperoleh dari Monitoring Screen Result (MSR) pada karyawan Grup Hubungan Kelembagaan di Bank DKI:

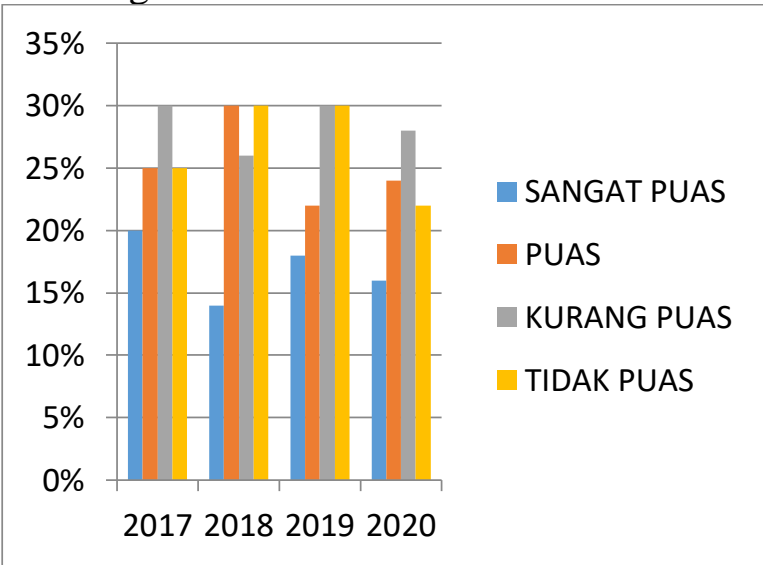

\section{Gambar 2. Penilaian MSR Nasabah Grup Hubungan Kelembagaan}

Faktor lain yang dapat berpengaruh terhadap kinerja adalah beban kerja. Beban kerja merupakan sekumpulan atau sejumlah kegiatan yang harus diselesaikan oleh suatu unit organisasi dalam waktu yang ditentukan (Noor and Rafiq, 2021). Berdasarkan uraian di atas menunjukan bahwa beban kerja pada karyawan Grup Hubungan Kelembagaan Bank DKI terdapat pekerjaan yang tidak diselesaikan pada poin hasil indeks kualitas program promo pemerintah dengan target nilai 100 dan hasilnya masih 70. Selain itu, dari tabel diatas hanya ada satu dari delapan indikator kinerja yang melampaui target yaitu monitoring perkembangan bisnis nasabah. Hal ini menunjukan bahwa beban kerja yang dijalankan oleh karyawan Grup Hubungan Kelembagaan Bank DKI lebih dari 50\% belum dilaksanakan secara optimal.

\section{METODE PENELITIAN}

Penelitian ini menggunakan metode penelitian kuantitatif. Menurut (Ghozali, 2016) penelitian kuantitatif menekankan pada pengujian teori melalui pengukuran variabel penelitian setelah sebelumnya dilakukan survey terhadap responden penelitian melalui kuesioner yang dibuat berdasarkan indikatornya. Penelitian ini dilakukan di Kantor Pusat Bank DKI dengan populasi penelitian adalah seluruh karyawan dan pemimpin setingkat Grup di Kantor Pusat Bank DKI. Teknik pengambilan sampel dalam penelitian ini adalah non probability sampling dengan metode convenience sampling. Sampel yang digunakan adalah seluruh karyawan dan pemimpin Grup Hubungan Kelembagaan di Bank DKI. Penelitian ini menggunakan data primer berupa kuisioner yang akan disebarkan ke karyawan yang bekerja di Grup Hubungan Kelembagaan di Bank DKI dengan media survey google form melalui email atau whats app dan juga dapat disebarkan secara langsung. Sementara Uji validasi menggunakan validasi Average Variance Extraced/AVE). Uji realibilitas dilakukan dengan Cronbach's alpha dengan nilai batas 0.7 .

\section{HASIL DAN PEMBAHASAN}

Responden dalam penelitian ini adalah seluruh karyawan dan pimpinan di Grup Hubungan Kelembagaan Bank DKI. Jumlah responden dalam penelitian ini adalah sebanyak 63 responden. Jumlah responden terdiri satu orang pemimpin grup, dua orang pemimpin divisi, 12 orang senior senior relationship officer, 33 orang relationship officer, 15 orang junior clerk. Masing-masing responden dalam penelitian memiliki tanggung jawab yang sama 
untuk mengisi seluruh pernyataan dengan jawaban yang tersedia.

\section{Uji Validasi}

Pengukuran uji validasi konvergen dilakukan pada nilai Average Variance Extracted (AVE) yang dimiliki oleh setiap variabel dengan standar nilai adalah $>0,5$. Berikut ini adalah nilai Average Variance Extracted (AVE) pada pengujian validitas diskriminan

Tabel 2. Hasil Pengujian Average Variance Extracted (AVE)

\begin{tabular}{lr}
\hline \multicolumn{1}{c}{ Variabel } & Nilai AVE \\
\hline Motivasi & 0.731 \\
Lingkungan Kerja & 0.727 \\
Kepuasan Kerja & 0.735 \\
Beban Kerja & 0.735 \\
TQM & 0.734 \\
Loyalitas & 0.738 \\
Kinerja & 0.729 \\
\hline
\end{tabular}

Sumber: Data Olahan

Berdasarkan tabel 2 diatas, dapat disimpulkan bahwa pengujian ini dilakukan untuk mengukur banyaknya variansi yang ditimbulkan dari masing-masing total konstruk variabel. Nilai yang dilihat dalam pengujian ini adalah nilai average variance extracted (AVE) pada semua variabel diperoleh sebagai hasil estimasi dimana nilainya $>0,50$ sehingga dapat dinyatakan valid. Hasil uji pada nilai average variance extracted (AVE) akan berguna untuk menjelaskan bagaimana setiap pernyataan didalam kuesioner pada masing-masing indikator dijumlahkan secara keseluruhan dalam menilai validitasnya.

\section{Uji Reliabilitas}

Pengujian reliabilitas dilakukan untuk mencari indikasi apakah indikator sesuai dengan kenyataan yang terjadi dan dirasakan oleh responden. Reliabilitas memiliki makna kesesuaian dan konsistensi jawaban terhadap pernyataan di setiap konstruk variabel penelitian. Pengujian reliabilitas pada penelitian ini menggunakan dua pengukuran yaitu nilai cronbach alpha. Pengukuran cronbach alpha mengukur keandalan indikator dan composite reliability mengukur konsistensi atas hasil jawaban responden penelitian. Berikut adalah hasil pengujian reliabilitas pada penelitian ini:
Tabel 3. Hasil Uji Reliabilitas

\begin{tabular}{lr}
\hline \multicolumn{1}{c}{ Variabel } & \multicolumn{1}{c}{$\begin{array}{c}\text { Cronbach's } \\
\text { Alpha }\end{array}$} \\
\hline Motivasi & 0.748 \\
Lingkungan Kerja & 0.734 \\
Kepuasan Kerja & 0.731 \\
Beban Kerja & 0.783 \\
TQM & 0.730 \\
Loyalitas & 0.820 \\
Kinerja & 0.726 \\
\hline
\end{tabular}

Sumber: Data Olahan

Berdasarkan Tabel 3 diatas dapat disimpulkan bahwa konstruk untuk semua variabel memenuhi kriteria reliabel. Hal ini ditunjukkan dengan nilai Cronbach's Alpha dan composite reliability yang diperoleh dari hasil estimasi SmartPLS. Nilai yang hasilkan adalah > 0,70 sebagaimana kriteria yang ditentukan didalam standar pengukuran.

Berdasarkan hasil penelitian yang dilakukan dengan statistic PLS, dapat disimpulkan bahwa masing-masing variabel eksogen tidak memiliki keterkaitan satu sama lain. Pengujian nilai signifikansi digunakan untuk menyatakan signifikan hubungan antar jalur untuk melihat kekuatan hubungan antar variabel. Nilai signifikan ini dapat diperoleh dengan prosedur bootstrapping yang menghasilkan nilai $\mathrm{T}$ ( nilai $\mathrm{T}>1,96$.) atau nilai $\mathrm{P}$ value $<0.5$. pada pengujian ini ditunjukkan bahwa hiptesis 1-8 diterima.

\section{Motivasi berpengaruh terhadap Kepuasan Kerja}

Motivasi mempunyai pengaruh positif dan siginifikan terhadap kepuasan kerja. Dengan demikian semakin termotivasi seorang karyawan dalam menyelesaikan pekerjaannya maka kepuasan kerja akan juga semakin tinggi. Kondisi ini sesuai dengan penelitian yang dilakukan oleh (Panagiotopoulos et al., 2018) menyatakan bahwa motivasi berpengaruh terhadap kepuasan kerja. Penelitian ini menjelaskan bahwa semakin tinggi motivasi seseorang untuk mencapai sasaran hidupnya maka akan berdampak langsung pada rasa puas dalam menyelesaikan pekerjaannya yang mempengaruhi peningkatan kinerja. Berdasarkan kondisi pada karyawan Grup Hubungan Kelembagaan di Bank DKI terlihat 
pada indikator didalam pernyataan kuesioner bahwa motivasi dapat mendorong karyawan untuk bekerja keras, mendukung karyawan untuk lebih percaya diri dan bertanggung jawab dalam melakukan pekerjaan, serta mengajak karyawan untuk selalu taat dan loyal terhadap peraturan perusahaan telah memberikan kontibusi terhadap peningkatan kinerja. Indikator motivasi ini sudah berjalan dengan baik di perusahaan agar terus ditingkatkan dan selalu diperbaharui. Adapun hal yang berhubungan dengan motivasi yang perlu diperhatikan adalah kebiasaan untuk memberikan pujian terhadap prestasi karyawan, disamping itu juga indikator suasana kerja juga sudah memenuhi kebutuhan fisik karyawan dalam menumbuhkan motivasi.

\section{Lingkungan Kerja berpengaruh terhadap Kepuasan Kerja}

Lingkungan kerja mempunyai pengaruh positif dan siginifikan terhadap kepuasan kerja. Dengan demikian kondisi lingkungan kerja dalam bekerja akan mempengaruhi kebiasaan karyawan bekerja dalam menyelesaikan pekerjaannya maka kepuasan kerja akan juga semakin tinggi. Kondisi ini sesuai dengan penelitian yang dilakukan oleh (Panjaitan and Frisda, 2019) menyatakan bahwa lingkungan kerja yang mendukung dan menciptakan nilai tambah bagi karyawan akan mempengaruhi tingkat kepuasan karyawan dalam menyelesaikan pekerjaannya. Berdasarkan kondisi pada karyawan Grup Hubungan Kelembagaan di Bank DKI terlihat pada indikator didalam pernyataan kuesioner yaitu kebutuhan sarana dan prasarana, psikologi dan sosialisasi antar karyawan baik didalam lingkungan pekerjaan ataupun diluar pekerjaan. Sikap sportifitas yang tinggi akan mendorong suasana nyaman dalam bekerja sehingga mempengaruhi kepuasan kerja karyawan. Indikator lingkungan kerja ini sudah berjalan dengan baik diperusahaan agar terus ditingkatkan dan selalu diperbaharui. Adapun hal yang berhubungan dengan lingkungan kerja yang perlu diperhatikan adalah kebutuhan psikologi karyawan yang menjadi perhatian perusahaan karena hal ini harus dilakukan secara konsisten agar karyawan memiliki ketahanan dalam bekerja, disamping itu juga indikator sosialisasi diluar pekerjaan yang melibatkan karyawan itu sendiri atau keluarganya dapat menambah rasa pengakuan diri karyawan untuk berkinerja dengan baik.

\section{Kepuasan Kerja berpengaruh terhadap Kinerja Karyawan}

Kepuasan kerja mempunyai pengaruh positif dan siginifikan terhadap kinerja karyawan. Dengan demikian kondisi kepuasan kerja dalam bekerja akan mempengaruhi keinginan bekerja yang maksimal dan berkualitas dalam menyelesaikan pekerjaannya sehingga meningkatkan kinerja. Kondisi ini sesuai dengan penelitian yang dilakukan oleh (Sarwono, 2019) menyatakan bahwa kepuasan kerja dan kinerja dapat menjadikan produktivitas karyawan lebih tinggi, sehingga hal ini menjadi tujuan prioritas organisasi. Berdasarkan kondisi pada karyawan Grup Hubungan Kelembagaan di Bank DKI terlihat pada indikator didalam pernyataan kuesioner yaitu faktor gaji, atasan dan kondisi operasional yang disediakan oleh perusahaan kepada karyawan selama hasil pekerjaan yang diberikan dapat mencapai target yang diberikan. Jawaban karyawan pada status ekonomi sosial juga menunjuka bahwa mayoritas dari sisi kesejahteraan, karyawan Grup Hubungan Kelembagaan Bank DKI telah berada pada posisi yang baik. Kepuasan kerja yang ditimbulkan ini akan mempengaruhi kinerja karyawan. Indikator lainnya yaitu rekan kerja juga sudah berjalan dengan baik diperusahaan, hal ini terlihat dari jawaban responden yang selalu interaktif dan diberikan kesempatan dalam memberikan pendapat dan mendukung satu sama lain dalam mencapai tujuan perusahaan sehingga semakin tinggi kepuasan kerja maka akan mempengaruhi kinerja karyawan.

\section{Beban Kerja berpengaruh negatif terhadap Kinerja Karyawan}

Beban kerja mempunyai pengaruh negatif dan siginifikan terhadap kinerja karyawan. Dengan demikian beban kerja akan mempengaruhi tekanan dalam bekerja yang disesuaikan pada setiap kemampuan karyawan dan tingkat jabatan karyawan. Semakin tinggi beban kerja maka dapat menimbulkan kejenuhan dan berdampak pada penurunan 
kinerja karyawan. Kondisi ini sesuai dengan penelitian yang dilakukan oleh (Tjiptono and Diana, 2017) menyatakan bahwa beban kerja berpengaruh negatif terhadap kinerja. Semakin besar beban kerja maka akan berpengaruh terhadap kemampuan produktifitas karyawan yang berdampak pada penurunan kinerja. Berdasarkan kondisi pada karyawan Grup Hubungan Kelembagaan di Bank DKI terlihat pada indikator didalam pernyataan kuesioner yaitu faktor tuntutan tugas bahwa semua karyawan mayoritas memilih pernyataan sangat setuju jika pada saat-saat tertentu karyawan bisa sangat sibuk dalam menyelesaikan pekerjaannya. Adanya perbedaan bobot kerja yang disesuaikan dengan jabatan karyawan akan mempengaruhi pengukuran penilaian kinerja karyawan Grup Hubungan Kelembagaan Bank DKI. Beban kerja berkaitan dengan satuan waktu yang diberikan kepada setiap karyawan untuk menyelesaikannya. Indikator lainnya yaitu usaha dan perfomansi. Hal ini berarti setiap karyawan yang mendapatkan beban kerja diberikan kesempatan untuk menyelesaikan pekerjaannya dengan usaha yang dilakukan dan produktifitas karyawan selama bekerja agar memanfaatkan waktu kerja sebaik-baiknya sehingga beban kerja tersebut dapat terbagi apabila dikelola dengan baik dan menghasilkan kinerja yang maksimal.

\section{TQM berpengaruh terhadap Kinerja Karyawan}

TQM mempunyai pengaruh positif dan siginifikan terhadap kinerja karyawan. Dengan demikian TQM akan mempengaruhi konsistensi karyawan dalam melakukan perbaikan secara berkesinambungan dalam mencapai kinerja. Semakin tinggi TQM maka dapat mempengaruhi peningkatan kinerja karyawan. Kondisi ini sesuai dengan penelitian yang dilakukan oleh (Ismunawan, 2018) menunjukan bahwa TQM berpengaruh terhadap kinerja karyawan. Hal ini dapat dikatakan bahwa praktik TQM ditujukan untuk melakukan perbaikan secara berkesinambungan (terusmenerus) terhadap produk atau jasa, SDM dan prosesnya. Berdasarkan kondisi pada karyawan Grup Hubungan Kelembagaan di Bank DKI terlihat pada indikator didalam pernyataan kuesioner yaitu fokus pada nasabah, dimana karyawan memahami dalam mengidentifikasi kebutuhan karyawan dan berfokus pada solusisolusi yang ditawarkan agar karyawan dapat melakukan fungsi hubungan kelembagaannya di Bank DKI. Karyawan yang berhasil melakukan TQM akan mempengaruhi penilaian kinerja karyawan Grup Hubungan Kelembagaan Bank DKI. TQM juga berkaitan dengan pelatihan dan pendidikan serta perbaikan going concern dalam menyelesaikan setiap pekerjaannya. Hal ini berarti setiap karyawan yang menjalankan TQM dengan prosedur dan berkesinambungan akan mempengaruhi karyawan untuk melakukan perbaikan dalam mencapai kinerja yang optimal dalam memberikan pencapaian yang terbaik bagi suatu organisasi.

\section{TQM berpengaruh terhadap Kinerja Karyawan dengan Loyalitas sebagai variabel Moderasi}

TQM mempunyai pengaruh positif dan siginifikan terhadap kinerja karyawan dengan loyalitas sebagai variabel moderasi. Semakin tinggi TQM yang diperkuat oleh rasa loyalitas maka dapat mempengaruhi peningkatan kinerja karyawan. Kondisi ini sesuai dengan penelitian yang dilakukan oleh (Siam and Kim, 2020) menyatakan bahwa TQM berpengaruh siginifikan terhadap kinerja dengan loyalitas sebagai variabel moderasi. Semakin kuat produktifitas karyawan yang diterapkan melalui proses TQM maka akan mempengaruhi kesediaan karyawan untuk bekerja secara loyal yang berdampak pada mutu atau kualitas kerja karyawan dalam mempengaruhi kinerja karyawan.

Berdasarkan kondisi pada karyawan Grup Hubungan Kelembagaan di Bank DKI terlihat pada indikator loyalitas yaitu taat pada peraturan dan tanggung jawab perusahaan didalam pernyataan kuesioner, dimana karyawan yang memahami prosedur, aturan dan cara bekerja secara konsisten akan memperkuat diri karyawan untuk melaksanakan TQM dalam mempengaruhi kinerja karyawan (Taheri et al., 2020). Loyalitas akan memperkuat cara karyawan yang berhasil fokus dalam memenuhi kebutuhan nasabah sehingga mempengaruhi penilaian kinerja karyawan Grup Hubungan Kelembagaan Bank DKI. Hal ini berarti setiap karyawan yang menjalankan TQM dengan rasa 
tanggung jawab yang diperkuat oleh loyalitas akan mempengaruhi karyawan untuk menghasilkan kinerja yang lebih baik.

\section{Beban Kerja berpengaruh terhadap Kinerja Karyawan dengan Loyalitas sebagai variabel Moderasi}

Beban kerja mempunyai pengaruh positif dan siginifikan terhadap kinerja karyawan dengan loyalitas sebagai variabel moderasi. Semakin tinggi beban kerja yang diperkuat oleh rasa loyalitas maka dapat mempengaruhi peningkatan kinerja karyawan. Kondisi ini sesuai dengan penelitian yang dilakukan oleh (Dewi et al., 2020) yang menyatakan bahwa loyalitas sebagai variabel moderasi dapat memperkuat pengaruh beban kerja terhadap kinerja karyawan. Hal ini dikarenakan kepuasan akan menimbulkan keinginan seseorang untuk melakukan yang terbaik bagi pencapaian atas dirinya sendiri dalam penilaian kinerja walaupun beban kerja yang dihadapi semakin berat. Kinerja karyawan yang dipengaruhi oleh kekuatan loyalitas akan menimbulkan keinginan untuk berada di dalam perusahaan dan bersama-sama dengan karyawan lainnya untuk mencapai tujuan perusahaan.

Berdasarkan kondisi pada karyawan Grup Hubungan Kelembagaan di Bank DKI terlihat pada indikator loyalitas yaitu rasa memiliki dan hubungan antar karyawan didalam perusahaan pada pernyataan kuesioner, dimana karyawan yang memahami bahwa perusahaan adalah tempat dimana karyawan memenuhi kesejahteraan hidupnya akan berusaha lebih maksimal dalam mengatasi tekanan pada beban kerja yang berdampak langsung terhadap kinerja karyawan. Loyalitas akan memperkuat cara karyawan untuk mengelolaa fikiran dan strategi pekerjaan yang menjadi beban kerja dalam mempengaruhi penilaian kinerja karyawan Grup Hubungan Kelembagaan Bank DKI. Hal ini mennjukan bahwa setiap karyawan yang memiliki pengendalian emosi, hubungan baik dan pengelolaan waktu yang tepat akan menumbuhkan rasa loyalitas sehingga mampu mengatasi beban kerja dan memperkuat peningkatan kinerja karyawan.

\section{Kepuasan Kerja berpengaruh terhadap Kinerja Karyawan dengan Loyalitas sebagai variabel Moderasi}

Kepuasan kerja mempunyai pengaruh positif dan siginifikan terhadap kinerja karyawan dengan loyalitas sebagai variabel moderasi. Semakin tinggi kepuasan kerja yang diperkuat oleh rasa loyalitas maka dapat mempengaruhi peningkatan kinerja karyawan. Kondisi ini sesuai dengan penelitian yang dilakukan oleh (Siam and Kim, 2020) menyatakan bahwa kepuasan kerja berpengaruh siginifikan terhadap kinerja dengan loyalitas sebagai variabel moderasi. Loyalitas memberikan kekuatan kepada kepuasan yang dirasakan untuk menghasilkan kinerja yang lebih baik.

Berdasarkan kondisi pada karyawan Grup Hubungan Kelembagaan di Bank DKI terlihat pada indikator loyalitas yaitu kesuksesan pekerjaan didalam perusahaan pada pernyataan kuesioner, dimana karyawan yang meraih kesuksesan dalam menyelesaikan pekerjaannya akan memperoleh balas jasa dari perusahaan dengan penilaian kinerja karyawan yang baik sehingga memperkuat kepuasan kerja melalui nilai kesejahteraan karyawan yang semakin tinggi (Poernomo, 2016). Loyalitas akan mendorong dan memperkuat kepuasan kerja karyawan untuk menghasilkan setiap pekerjaan dengan kualitas yang dapat dipertanggung jawabkan oleh karyawan pada saat penilaian sehingga mempengaruhi kinerja karyawan Grup Hubungan Kelembagaan Bank DKI

\section{KESIMPULAN}

Setelah melalui proses penelitian akhirnya peneliti dapat menarik kesimpulan penelitian sesuai dengan permasalah dalam penelitian yaitu:

1. Kinerja karyawan di Bank DKI didominasi oleh efektifitas kerja dan kemandirian karyawan.

2. Faktor-faktor yang mempengaruhi kinerja karyawan disimpulkan sebagai berikut:

a. Motivasi memiliki pengaruh positif dan signifikan terhadap kepuasan kerja..

b. Lingkungan Kerja memiliki pengaruh positif dan signifikan terhadap kepuasan kerja. 
c. Kepuasan kerja berpengaruh positif dan signifikan terhadap kinerja karyawan.

d. Beban kerja berpengaruh negatif dan signifikan terhadap kinerja karyawan.

e. TQM berpengaruh positif dan signifikan terhadap kinerja karyawan..

f. TQM berpengaruh signifikan terhadap kinerja karyawan dengan loyalitas sebagai variabel moderasi.

g. Beban kerja berpengaruh signifikan terhadap kinerja karyawan dengan loyalitas sebagai variabel moderasi.

h. Kepuasan kerja berpengaruh signifikan terhadap kinerja karyawan dengan loyalitas sebagai variabel moderasi.

3. Implikasi manajerial pada penelitian ini berdampak pada pemikiran dan pemberian solusi kepada jajaran manajemen untuk langkah-langkah dalam upaya meningkatkan kinerja karyawan.

\section{SARAN}

1. Bagi pemimpin Grup Hubungan Kelembagaan Bank DKI agar terus berkesinambungan untuk menerapkan TQM saat memotivasi karyawannya

2. Bagi karyawan agar dalam pelaksanaan tugas dan pengabdian sebagai pelayan publik di industri bank daerah maka hendaknya terus melalukan perbaikan melalui konsep TQM.

3. Bagi penelitian agar mengkaji lebih dalam mengenai motivasi dan kepuasan kerja dari pemenuhan kebutuhan sementara kebutuhan masing- masing karyawan pada umumnya berbeda yang disebabkan oleh keadaan yang berbeda pula.

\section{DAFTAR PUSTAKA}

Akrani, A. S. 2018. Manajemen Sumber Daya Manusia. Jakarta: Pustaka Sinar Harapan.

Al-Damen, R. A. 2017. The Impact of Total Quality Management on Organizational Performance Case of Jordan Oil Petroleum Company. International Journal of Business and Social Science, 8(1), 192-202.

Dewi, P., Budiyanto, and Agustedi. 2020. The
Role of Loyality in Moderating the Effect of Work Load on Employee Performance. Accounting, 6(7), 12171226.

https://doi.org/10.5267/j.ac.2020.9.005

Ghozali, I. 2016. Desain Penelitian Kuantitatif Dan Kualitatif. Jakarta: Salemba Empat.

Ismunawan, U. 2018. Pengaruh Pengawasan Terhadap Disiplin Kerja Pada Kantor Kecamatan Samarinda ULU Kota Samarinda. Jurnal Komunikasi Dan Ilmu Sosial.

Kartika, Surachman, and Ratnawati. 2018. Pengaruh Kepemimpinan Dan Beban Kerja Terhadap Kinerja Karyawan Pada CV Putra Kaltim Samarinda. Jurnal Universitas Negeri Surabaya, 4(1).

Noor, S., and Rafiq, M. A. 2021. Discover the Employee Performance Dimensionality in Public Sector Organizations of Pakistan. PalArch's Journal of Archaeology of Egypt/Egyptology, 18(4), 4991-5021.

Panagiotopoulos, G., Petta, E., and Karanikola,

Z. 2018. The Contribution of Motivation To Job Satisfaction: A Survey Of Technological Educational Institute Employees of Western Greece. European Journal of Training and Development Studies, 5(3), 18-26.

Panjaitan, W. O., and Frisda, K. 2019. Analisis Efek Mediasi Lingkungan Pada Pengaruh Kepuasan Kerja Terhadap Kinerja Pegawai. Tesis Fakultas Manajemen Universitas Negeri Jakarta.

Poernomo, M. 2016. Pengaruh Kepuasan Kerja Terhadap Kinerja Karyawan Pada PT Primarindo Asia Infrastruktur, Tbk. Jurnal ISSN 2355-9357 Vol 3 No 2, $3(2)$.

Sallis, E. 2017. Total Quality Management. Jakarta: Kogan.

Sarwono, W. S. 2019. Psikologi Remaja: Definisi Remaja. Jakarta: Raja Grafindo Persada.

Siam, L. H., and Kim, T. H. 2020. The Moderating Effect of Loyality on Total 
Quality Management and Satisfaction by Employees , Performance. International Journal of Environmental Research and Public Health, 17.

Taheri, R. H., Miah, M. S., and Kamaruzzaman. 2020. Impact of Working Environment on Job Satisfaction. EPRA International Journal of Multidisciplinary Research (IJMR), 5(6), $\quad$ 403-406. https://doi.org/10.36713/epra4849

Tjiptono, and Diana. 2017. Pengaruh Reward Dan Punishment Terhadap Kinerja Pegawai Pada PT. Perkebunan Nusantara III Rambutan. Tesis Universitas Dipenogoro. 